\title{
INTERACTIVITY, EXPRESSIVENESS AND \\ ENGAGEMENT IN NEWSGAME “BACK TO 1964: YOUR LIFE UNDER THE DICTATORSHIP"
}

\author{
Lilian Cristina Monteiro França
}

\begin{abstract}
In 2014, a series of events marked the 5oth anniversary of the military coup in Brazil. The popular Superinteressante magazine launched a review of the facts through the newsgame "Back to 1964: your life under the dictatorship". The purpose of this research paper is to analyze the newsgame, considering its expressiveness, engagement and experience proportionate to the player. The analysis draws heavily on concepts developed by Frasca (2001), Bogost (2008), Bogost, Ferrari \& Schweizer (2010), lurgel \& Zagalo (2009), Ferrari (2009), Gonçalves \& Zagalo (2010), Zagalo (2012), Sicart (2008), among others. The experiences with the game were used to categorize the levels of interactivity and reactivity, according to the possible paths followed by the reader/player. The extent to which the proposed simulation delineated narratives linked to the editorial profile of the magazine, and to what extent this can be used to encourage public debate.
\end{abstract}

KEYWORDS

Newsgames; interactivity; expressiveness; engagement

\section{INTRODUCTION}

The concept of 'newsgames' was originally developed by Gonzalo Frasca who defined them as "the encounter between journalism and political cartoons". Bogost, Ferrari \& Schweizer (2010: 13) extended Frasca's pioneering research, broadening the definition to include "any intersection of journalism and gaming". To Déda \& Zagalo (2010). Newsgames allow journalists to create interactive models of information transmission, making the journalism more participative while still acting as a mobile platform for dissemination (Déda \& Zagalo, 2010: 130).

Newsgames have arisen during the "gamification" of society and the advent of online journalism. In this context, "gamification" can be thought of as the process of taking video games out of their entertainment function to generate partnerships with other functional areas (education, journalism, cinema, etc.). Such a transfer of functions creates new narrative forms, increasing accumulated knowledge and practices through electronic games. According to the games' expert lan Bogost (2008: 119), "[...] the people who play video games develop values, strategies, and approaches to the practice of play itself". The events that take place "within" the game space unfold everyday experiences, modifying and producing the world view of the player. The relationship of the player and the video game is intensified through technological developments that provide increasingly realistic approximations of real situations, favoring increasing immersion in the game environment. 
At the same time, technological developments impact the journalistic field, jeopardizing its traditional structure that is still anchored in the production of printed content and sustained by the profits arising primarily from advertising revenue. At a time of financial crisis (business models, support, advertising, access and relevance) and an increasingly competitive environment in which companies must compete among themselves and with the journalistic production arising from collaborative sites and social networks, journalistic organizations have become more open to innovation. For example, through online editions, applications (apps) for mobile devices (smartphones and tablets), formation of multidisciplinary teams and restructuring the logic narrative of content - often referred to collectively as "new media".

The collision between traditional media and new media, as understood by Jenkins (2006:11), takes place in an era of convergence: "Welcome to convergence culture, where old and new media collide, where grassroots and corporate media intersect, where the power of the media producer and the power of the media consumer interact in unpredictable ways". Such a view represents a new paradigm for thinking about society, grounded in media convergence, participatory culture and collective intelligence.

Working with this new paradigm demands a revision of old certainties underlying and guiding theoretical reflection. Newsgames are particularly interesting in this respect, since they sit at the intersection of old and new media, uniting the seriousness of good journalism with the playful nature of video games within new forms of narrative structure. This paper draws heavily on the concepts outlined above to analyze the Brazilian newsgame "Back to 1964: your life under the dictatorship," released in April 1, 2014, by Superinteressante magazine. This date had a special significance, being the anniversary of the coup that led to twenty years of military dictatorship in Brazil.

Given the focus on expressiveness and engagement in the game experience, the levels of interactivity (linear, hierarchical, support, simulation, hyperlinks) and reactivity were categorized according to the possible pathways to be followed by the reader/player. The analysis allows us to see to what extent the simulation exercise delineated narratives linked to the editorial profile of the magazine, and to what extent the game was able to stimulate public debate and contribute to a particular understanding of the meanings of the Brazilian coup of 1964 .

\section{INTRODUCING THE NEWSGAME "BACK TO 1964: YOUR LIFE UNDER THE DICTATORSHIP"}

The year 2014 marks the 5oth anniversary of the military coup in Brazil. This anniversary received special attention from media' in the second half of 2013 . This attention took the form of a series of events that, together, formed a historical review of that critical moment in the contemporary history of Brazil. Each media vehicle sought to find a way to discuss a topic that has impacted the lives of millions of Brazilians and changed the destiny of the nation.

'Although not the purpose of this analysis, it is necessary to point out that in the Brazilian dictatorial scenario some media outlets were regarded as a strong arm of the military dictatorship. 
Aiming to engage in this historical discussion, the popular magazine, Superinteressante, chose to produce its anniversary content in a newsgame format. This reflects a wider trend that is being adopted by many major media vehicles worldwide. Bogost, Ferrari \& Schweizer (2010: 10), in their article - NewsGames: journalism at play - suggest that journalism has a pressing need to develop innovative perspectives to remediate the effects of the global journalism crisis and to respond to the need to develop new business models and new languages: "journalism can and will embrace new modes of thinking about news in addition to new modes of production".

Superinteressante was launched in 1987 by Editora Abril with the aim of working in the science communication field. The magazine has successfully gained the public's trust, becoming respected as a vehicle for scientific literacy and capturing a loyal readership for their print editions and (subsequently) digital editions. ComScore (2014) research reported that the magazine received $11,482,000$ page views and 3,189,000 unique visitors in the preceding month, with an audience of $55 \%$ male and $46 \%$ female readers. The readership is typically young middle class adults with $87 \%$ of readers ranging from 15 to 34 years (36\% of them between 15 and 19 years), of which $11 \%$ belongs to class $A$, $61 \%$ to class $B$ and $27 \%$ to class $C$ (class D represents only $1 \%$ and class $E$ has no representation, o\%).

The magazine's profile is particularly attractive to young people, especially those who attend the secondary and higher education. Responding to this important demographic, the magazine's editors have invested in developing new languages for scientific dissemination, including newsgames. Indeed, Superinteressante was a pioneer in creating news-based games in Brazil. Superinteressante is published by the Youth Core of Editora Abril launched the newsgame "CSI - Science against crime" in 2008. This game garnered considerable interest, encouraging further investment by the magazine in newsgames. "Filosofighters", "O jogo da Máfia", "A evolução do Movimento" and "Corrida Eleitoral", are among the most accessed Superinteressante newsgames.

The newsgames prepared by the publisher Youth Core - directed in 2008 by Fred di Giacomo Rocha, who was also responsible for bringing the format to the magazine - turned out to be an inspired marketing tool, and have since become part of Superinteressante's routine production. The challenge of producing content about the 1964 coup to an eminently young audience, prompted the editors to build a newsgame that simulated some of the situations that the Brazilian population faced in this period. This gave rise to the newsgame "Back to 1964: your life under the dictatorship" (Figure 1), a title that nods towards Robert Zemekis' (1995) movie "Back to the Future". Indeed, the key question for the game is: "Imagine if you woke up on March 31, 1964?" 


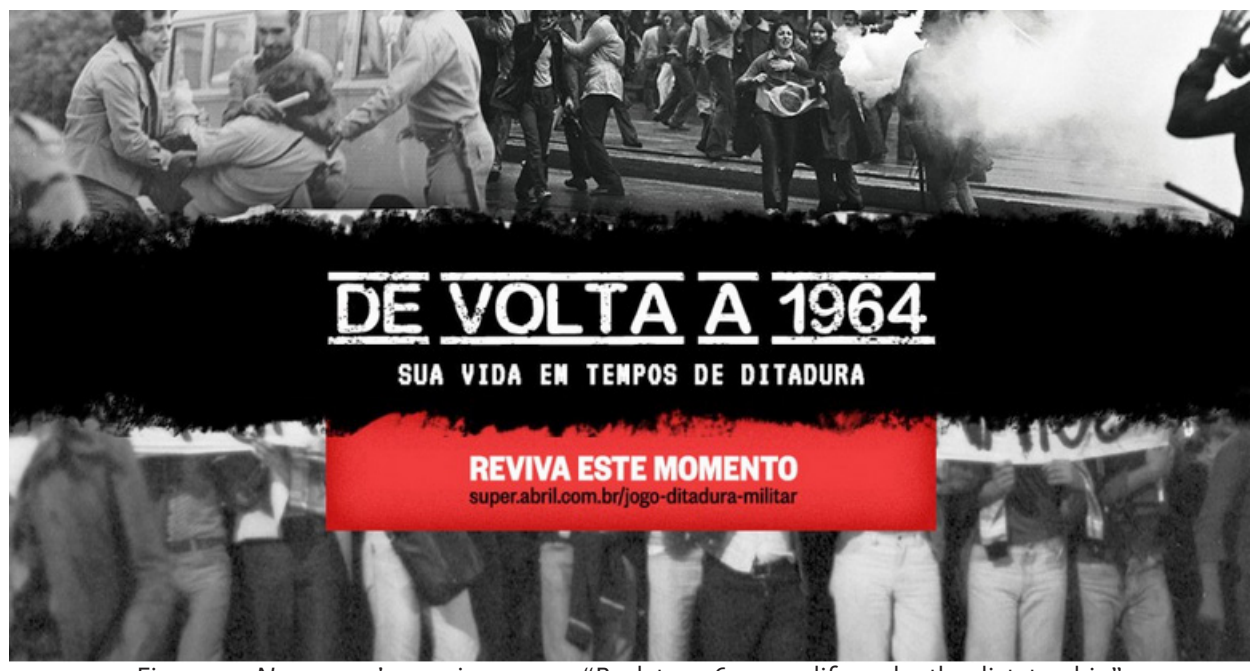

Figure 1- Newsgame's opening screen "Back to 1964: your life under the dictatorship"

The Superinteressante blog written by Mariana Nadai explains the newsgame in the following way:

A time of hard decisions. It is with this premise that we, the copywriters of SUPER, set out to look at the 50 year anniversary of the Brazilian military coup on April 1, 2014, and the 21 years of dictatorship that immediately followed. But, to decide the focus was only part of what would be special about the period. It was necessary, above all, know how to demonstrate this historic moment for our readers (Blog da Super, 2014).

The introductory text of the game frames the 50 year anniversary of the military coup as an event to be commemorated. According to the Houaiss Dictionary, the word commemorate means: 1. to bring to memory, recall, memorialize; 2 . to make a commemoration, performing a ceremony of evocation; 3. to commemorate with festivity, festivity. The term "commemorate" can produce different meanings, the most commonly used of which refers to a situation that deserves to be shared with joy: e.g. "commemorate the victory", "commemorate a birthday". Its use is less frequent in cases of death and tragedies, for example, is hardly to find expressions such as "commemorate the death", "commemorate the tragedy" or "commemorate the attack", and when this happens it is seen as a gaffe that merits an apology.

The public profile of Superinteressante is composed mainly of young people between 15 and 34 years, born just before or after the dictatorship. Consequently, the expression "commemorate the $1^{\text {st }}$ of April 2014" provides a novel editorial line adopted. Searching Google with the Portuguese phrase "commemorate the $1^{\text {st }}$ April 2014" only returned six results and all refer to the Superinteressante Blog's that gave the date contours of joy, whether it was voluntary or involuntary.

The second paragraph of the game introduction continues:

How would we deal with an ephemeris that Brazil (or at least all the well-known media) was talking about? In times of 'snowfallization' of information, I will 
not deny that we even thought of making the coup content with parallax effect. But our roots spoke louder and we thought this would be the best time to return to production of a model that we pioneered in Brazil: the newsgame. Thus, "Back to 1964 - your life under the dictatorship" was born (Blog da Super, 2014).

The Superinteressante team mentions the multimedia article "Snow Fall" of published in 2012 in the New York Times. This article won the Pulitzer Prize and was the most viewed article of the year, although it was only published in December. The success of the article gave rise to the term snowfallization, to refer to the transformation of standard news formats into extensive multimedia projects.

Brazilian media quickly picked up on this new trend. In 2013, the Brazilian newspaper Folha de S. Paulo launched the Tudo Sobre (All About) series with the special Batalha de Belo Monte (Battle of Belo Monte). At the same time the G1 news portal published Buy buy Brasil. Both of these articles closely followed the multimedia example of Snow Fall. The Superinteressante editors have shown interest in following the same path, which is why "Back in 1964" used a hybrid structure, bringing together elements of newsgame and multimedia documentaries.

A third point highlighted in the game introduction is the short time available for the development of the game: "From then on, it was a race against time. We only had two months to investigate, write, draw and program the game" (Blog da Super, 2014). As already mentioned, all the national media was organized from the second half of 2013 to address the 50 years of the coup. The late decision of Superinteressante to join this discourse perhaps reflects the perceived need to be part of the discussion.

Concluding the game introduction, Mariana Nadai invites the readers to get to know the game: "As the idea is not only to play, but also to learn with the game. You will be given a complete timeline on the military dictatorship years in Brazil. Are you curious to know what would have been your fate under the dictatorship? Do not waste time. Play now!" (Blog da Super, 2014). Once more it seems that the event was handled in a "light" way, trying to associate the experience with "play", a fact that somehow reduces the complexity of the coup for a country that spent nearly 20 years under military dictatorship. In the words of Bogost, Ferrari \& Schweizer (2010: 10),

Newsgames are not a charmed salve that will cure the ills of news organizations overnight. But they do represent a real and viable opportunity to help citizens form beliefs and make decisions.

The authors state that newsgames should always take into account the seriousness of the premise. Its content should provide the reader with information, critical thinking development, allowing them to take a stand and develop in depth knowledge on relevant topics. The playfulness should be the guiding principle in a newsgame, but the predominant feature cannot be the entertainment.

The issues highlighted in the game introduction serve as pre-suppositions of the whole narrative structure of the newsgame, making clear the standpoint of Editora Abril 
and a perspective of "retaliation", as can be seen throughout the game, as will be further discussed.

\section{INTERACTIVITY, EXPRESSIVENESS AND ENGAGEMENT IN "BACK TO 1964"}

Interactivity and participation are concepts that are sometimes taken as synonymous. For the purpose of the current analysis, the concepts will be treated according to the definitions proposed by Jenkins (2006):

Interactivity refers to the ways that new technologies have been designed to be more responsive to consumer feedback. One can imagine differing degrees of interactivity enabled by different communication technologies, ranging from television, which allows us only to change the channel, to video games that can allow consumers to act upon the represented world [...] Participation, on the other hand, is shaped by the cultural and social protocols. So, for example, the amount of conversation possible in a movie theater is determined more by the tolerance of audiences in different subcultures or national contexts than by any innate property of cinema itself. Participation is more open-ended, less under the control of media producers and more under the control of media consumers (Jenkins, 2006: 142).

The game script that follows will therefore be guided both in the alternatives proposed by the game producers (interactivity) and in the possibilities of player engagement (participation).

The narrative structure of the game is based on the logic of binary oppositions that determine which path is followed to reach a certain outcome. A screen appears for each option chosen, indicating what percentage of players made the same choice.

Firstly, the newsgame "Back to 1964" should be characterized. Bogost, Ferrari \& Schweizer (2010) identify seven types of newsgames: current events, infographics, documentary, puzzles, platforms, literacy and community. "Back to 1964" most closely resembles a current event game, as defined by the authors:

Current event games have low system requirements and wide distribution at online game portals in addition to the Web sites of their sponsoring organizations. They are often created in Adobe Flash, a multimedia technology with nearly universal access that can be embedded directly in Web pages. Producing a current event game does not pose technical challenges, but logistical ones. Their creators must balance timeliness with quality, deciding whether games should cover an isolated political issue or an ongoing social issue. Because they are short and compact, current event games have to work hard to ensure their players immediately understand the context and constraints of the topic and the game's approach to it. Some current event games explicitly state the facts via text or video, whereas others follow 
Fracas's lead and attempt to sway opinion through play alone (Bogost, Ferrari \& Schweizer, 2010: 15).

The game was widely distributed, being produced in HTML 5. In addition to being structured around decisions taken by the reader, the game displayed a timeline, videos and photos. Bogost, Ferrari \& Schweizer (2010) sub-divided current event games into: editorial games, tabloid games, and reportage games. In this sense, "Back to 1964" is an editorial game: "Editorial current event games are games with an argument, or those that attempt to persuade their players in some way" (Bogost, Ferrari \& Schweizer, 2010: 15).

The opening screen of "Back to 1964" offers three possibilities to the player: "display a video", "start" and "timeline" (Figure 2).

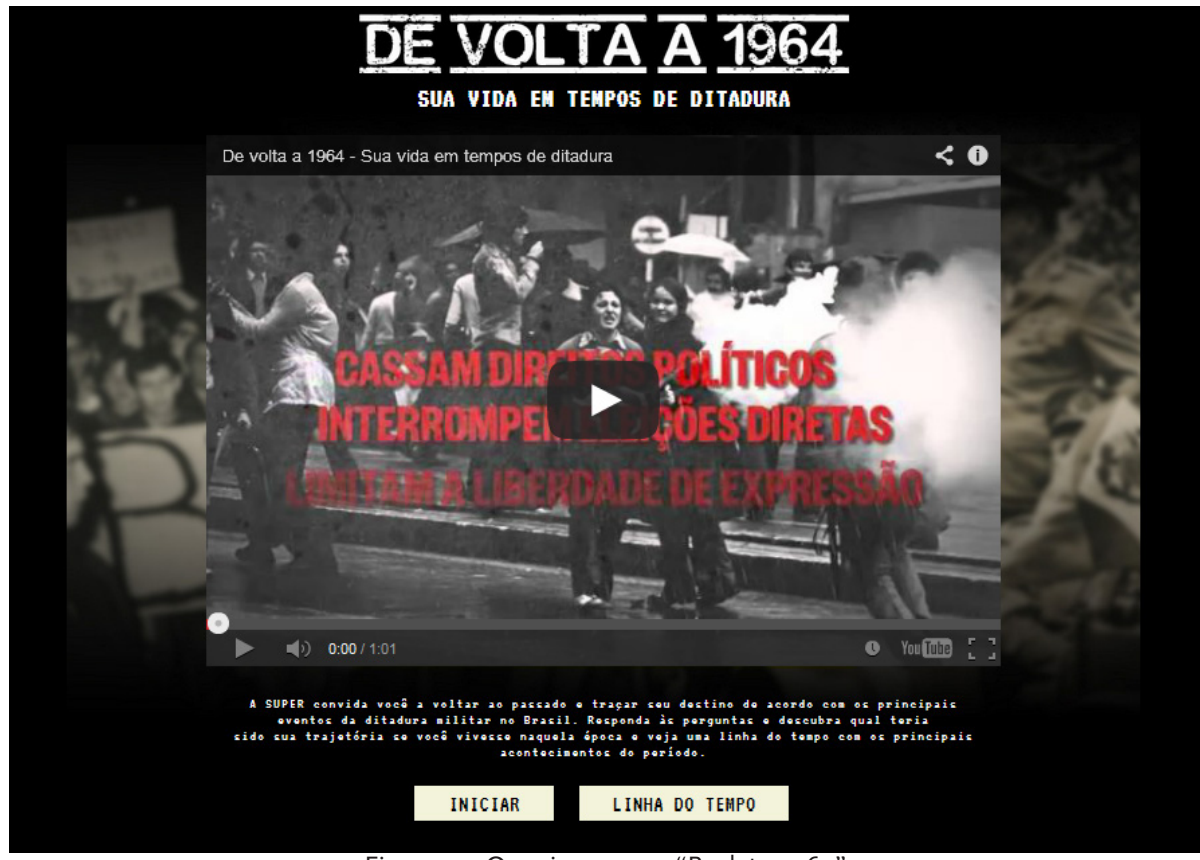

Figure 2 - Opening screen "Back to 1964"

The video, hosted on YouTube, lasts one minute and is a retrospective of the establishment of the dictatorship. Photos (black and white) and newspaper headlines (subtitled in red) are shown. This format dramatically demonstrates the "time of hard decisions", including a photo of the journalist Vladimir Herzog hanged in his prison cell at Destacamento de Operações de Informações - Centro de Operações de Defesa Interna (DOI-CODI) after his arrest by the military regime. The video is mainly a summary and an invitation to the game.

The video had 36,693 views (until September 30, 2014) in the Superinteressante channel on You Tube with 106 likes and 22 dislikes. This is rather an impressive number given the magazine readership and the prominence given by the media to the 5oth anniversary of the coup. However, the degree of involvement was very small - only 128 people who viewed the video had given their opinion on it (0.35\%) and $17 \%$ indicated they did not like it (dislike). 
This fact might be due to the rather static nature of the video, being composed only of animated images from photos and newspapers with short and punctual captions in capital letters, e.g. "Military draw the power of President João Goulart"; "The military dictatorship is established in Brazil"; "Military interrupts guarantees of democratic government"; "Political rights are taken out"; "Direct elections are interrupted"; "Freedom of expression is strictly limited"; "Opponents are arrested, tortured and killed"; "The military regime ends 21 years after the coup"; "Even today, the era of crimes remains without investigation, trial or punishment"; "A period of difficult decisions" and "Relive this moment". Reproductions of the first three pages of the newspaper Última Hora (from Rio de Janeiro), with the headlines "Government troops on the border with Minas Gerais" (31/03/1964), "Uprising in Minas Gerais to depose Jango" (01/04/1964) and "Institutional Act was enacted" (04/10/1964) intersperse the photos.

Última Hora was the only newspaper favorable to the deposed President, aligning with the Superinteressante editorial viewpoint. Notably, the position of other vehicles was avoided. For example, Jornal do Brazil, (edition April 1, 1964) carried the headline: "São Paulo joins Minas Gerais and announces the march to Rio against Goulart", on the same day the Folha de S. Paulo also published: "São Paulo stopped yesterday in order to defend the regime". It should be noted that Última Hora was bought in 1971 by the company Folha da Manhã, the same company that produces Folha de S. Paulo.

The "timeline" (Figure 3) starts in 1961 when the first events are the resignation of President Jânio Quadros and the government years of João Goulart (Jango) until the coup in 1964. The timeline shows photos and videos, but there are no links to other content, which could widen the informational capacity of the game. The last event of the timeline is the election of President Tancredo Neves, elected by popular vote as a result of the movement "Diretas já" in 1985.

Clicking on "start", the reader must register some data, as explained the newsgame: "Calm down, we're not monitoring your data, it will only help Super to do a story on the game" (Redação Super, 2014). The required data are: age, gender and State (valid for Brazilian States - if someone lives in another country, no record is possible).

The next step is for the player to read a text about the global context, citing the Cold War, and an invitation to choose whether to accept or not the invitation to join the "Marcha da Família" (March of the Family). Every choice determines a different route, which will generate new options, until the end of the game. For those who select "yes" (the newsgame reports that $36 \%$ of players make this decision) two new possibilities are offered: "to meet" or "stay home". For those who decide "to meet" (56\% of the players do) the next step is a choice between "off the bus" or "back home" after seeing police and leftists near to the university.

As mentioned, the game is based on binary oppositions. For those who selected "off the bus" an invitation is made to participate in a discussion about the resistance movement against the Military Regime ( $82 \%$ of the players attend). The narrative then goes further allowing for players to engage in "Luta de Massas" (Mass Struggle) or "Luta Armada" (Armed Struggle). However, there is no information that supports this decision: 
there is no explanation of what constitutes a mass struggle or the implications of armed struggle. Nevertheless, $24 \%$ of the players still chose the second option, fighting alongside the guerrillas led by Carlos Marighella.

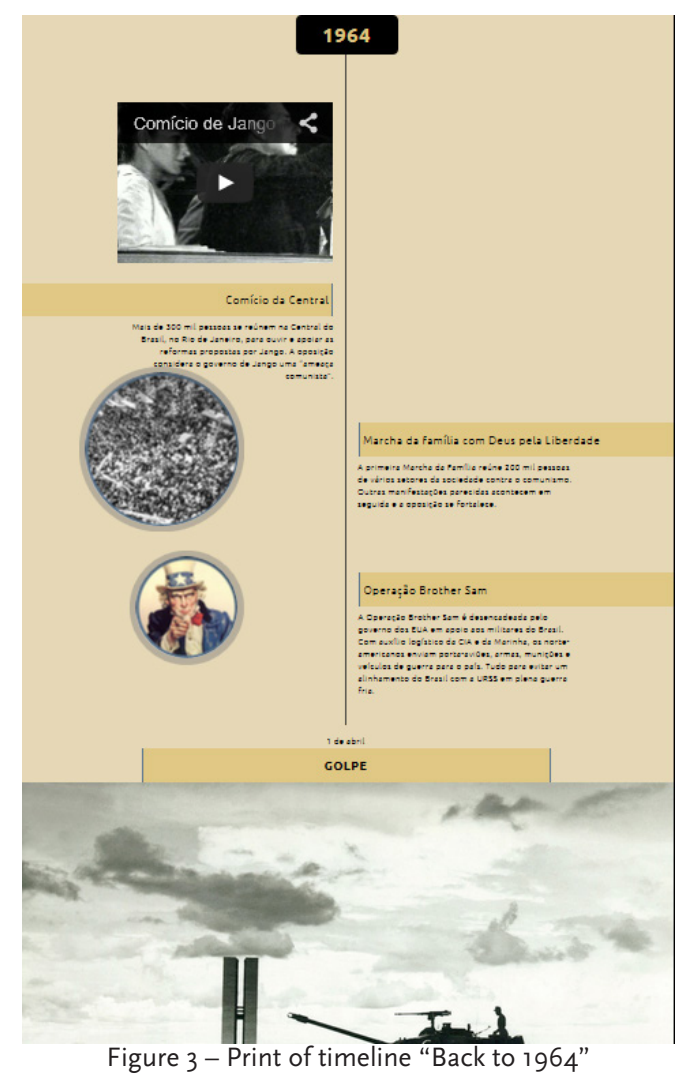

Then comes a warning: "Caution: For this situation you will have only 60 seconds to answer (if you do not respond in the given time we will pick one option for you)" (Redação Super, 2014). After reading a brief text explaining rural guerrilla warfare, the player must decide whether to "participate" or "non-participate". Perhaps unsurprisingly given the demographic of the readership, $73 \%$ of the players choose to participate.

The final screen shows the overall result: e.g., "7\% of respondents had the same outcome as you" (Redação Super, 2014). The outcome for those who decided to accept all the invitations are then presented:

What country is this? You decide to participate in the rural guerrilla warfare and go to the Araguaia River in Pará State. But this location is discovered by the Army and you are brutally murdered. The violence also affects residents. Officers cut the head and hands of the victims and leave them in bags for identification by the Army. According to the military estimates, more than 80 guerrillas die (Redação Super, 2014) (emphasis in original).

The screen shows the stylized drawing of a murdered young man (Figure 4). 


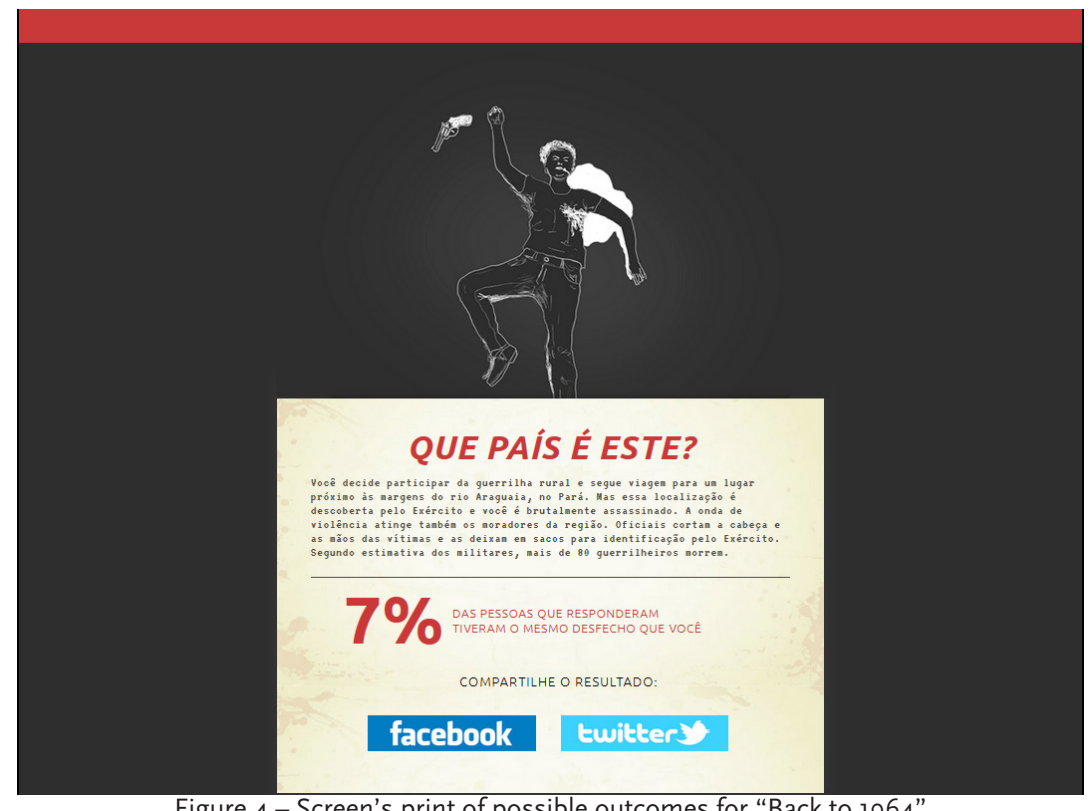

Figure 4 - Screen's print of possible outcomes for "Back to 1964 "

The game leads to other similar outcomes (Figure 5), making the player realize that basically there are two paths: one taken by those who demonstrate greater political engagement and other taken by those who prefer to distance themselves from such issues.

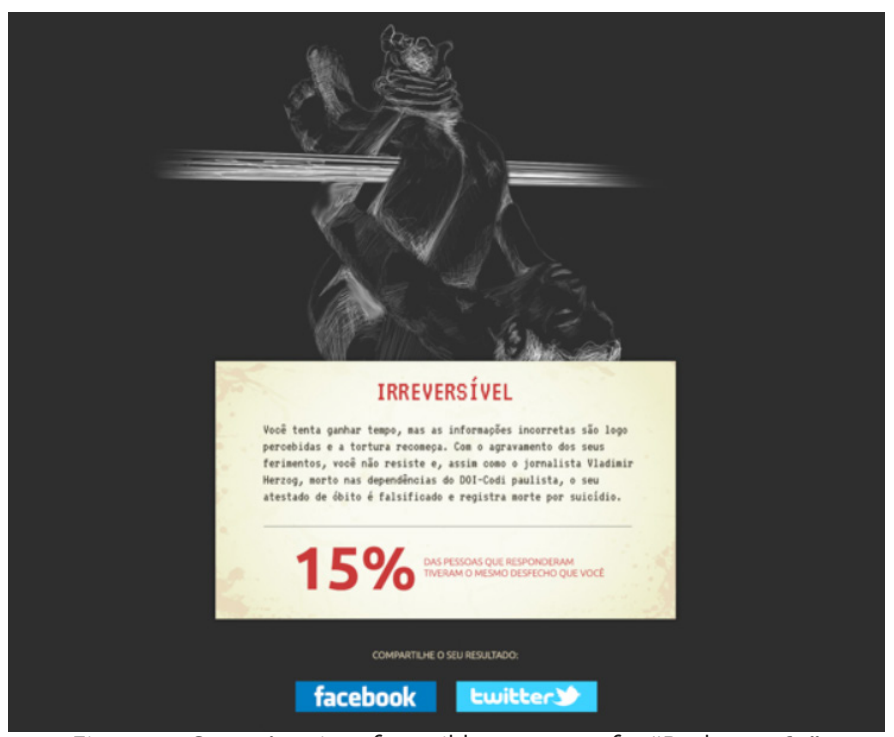

Figure 5 - Screen's print of possible outcomes for "Back to 1964

The path described above is one of the many possible pathways available. According to Sims, three types of interactivity can be identified via the web:

Support Interactivity: assistance with topics, introduction of tutorials and predetermined paths to follow; Simulation Interactivity: the user related actions that are possible in reality; Hyperlinks Interactivity: the user has available paths to navigate and can be directed to a different path from the previous (Sims apud Almeida, 2003: 8). 
Based on this classification, the narrative structure of "Back to 1964" contains simulation interactivity, as the player must take the role of someone facing the 1964 military coup. It also contains hyperlinks interactivity to the extent that the players choose the way to be followed. However, the degree of interactivity is low, since the options throughout the game boil down to "to go" or "not to go", "to participate" or "not to participate", "to accept" or "not to accept".

The newsgame is constructed using a hypertext structure, the same way as other Superinteressante games, e.g. CSI- A Ciência contra o crime (Science against crime). Primo (2003:3) comments, "If before, participation rhymed with discussion, today participation rhymes with point/click. In this scenario, the more "clickable" a website, the more interactive it is (even if all the reactions of links and buttons are already specified in the schedule/forecast)". In this sense, "Back to 1964" is hardly "clickable" since there are only seven steps (in the way described) after starting the game.

According to Sicart (2008: 32), newsgames are: "Serious games designed to illustrate a specific and concrete aspect of the news by means of procedural rhetoric, with the goal of participating in the public debate". Thus, the matters addressed by "Back to 1964" deserved better attention, expanding the possibilities for interaction and participation through discussion of significant issues for the country. Earlier in this paper, it was mentioned that the game was created very quickly and it seems likely that the development team lacked time to build in more connections.

There is a vast amount of material about the 1964 coup which was not considered for the newsgame, including videos, maps and documents. Searching for "Back to 1964: your life under the dictatorship" in Google search only retrieves 357 pages, almost all limited to reviews of the game. Moreover, the material mentioned at the beginning of the game has not yet been released. As the newsgame was framed in the category of editorial games, one must keep in mind some aspects of this structure type to proceed with the analysis.

In fact, Ferrari (2009) differentiates newsgames from editorial games:

The line between "newsgame" and "editorial game" is fuzzy no matter how you slice it. Basically, our suggestion is that most games called "newsgames" don't have the same intentions or goals as traditional reporting, or "the news," but rather those of the op-ed piece: to persuade; therefore, we should label these digital opinion pieces as "editorial" rather than "news." Most people are probably inclined to ignore the possible distinction, because there doesn't seem to be enough proof that we need one in the first place (we can't exactly place a finger on what a "properly journalistic" newsgame would look like, as Paolo Pedercini has pointed out to us before). By the end we will (hopefully) have a slightly better understanding of the relationship between editorial and newsmaking, as well as a firmer grasp on how procedural rhetoric is used in editorial games (Ferrari, 2009: 1).

"Back to 1964" seems to be much more an editorial game than a newsgame, since the focus is not on the news. Editorial games tailor the narrative and the information 
emerges synthesized and tied to a particular viewpoint. For example, in one of the possible response pathways of the game, the following question arises: "Do you like your job, despite not having a good salary? A friend shows you a position in a big company where you will have a higher salary to do a lot more boring and bureaucratic work. Which do you prefer?" (Redação Super, 2014). Which is the purpose of this question? Does it actually relate specifically to the coup? Those who choose to remain in their old job receive the following message:

JOY, JOY. You decide to prioritize a simpler way of life and work in the same job for many years. Despite being informed about what happens in Brazil, you are not directly affected by the iron hands of the regime. After the redemocratization of Brazil, you move further away from politics and usually void your votes (Redação Super, 2014).

This result suggests that a life of political apathy, little engagement and without big ambitions leads to a happy life (Figure 6). The speech contained in the highlighted section shows the distance between the game's narrative and the narrative of the facts, as found in the passage: "Despite being informed about what happens in Brazil, you are not directly affected by the iron hands of the regime" (Redação da Super, 2014). It does seem that the player does not live in Brazil or that the player can live in a military dictatorship without being affected by it.

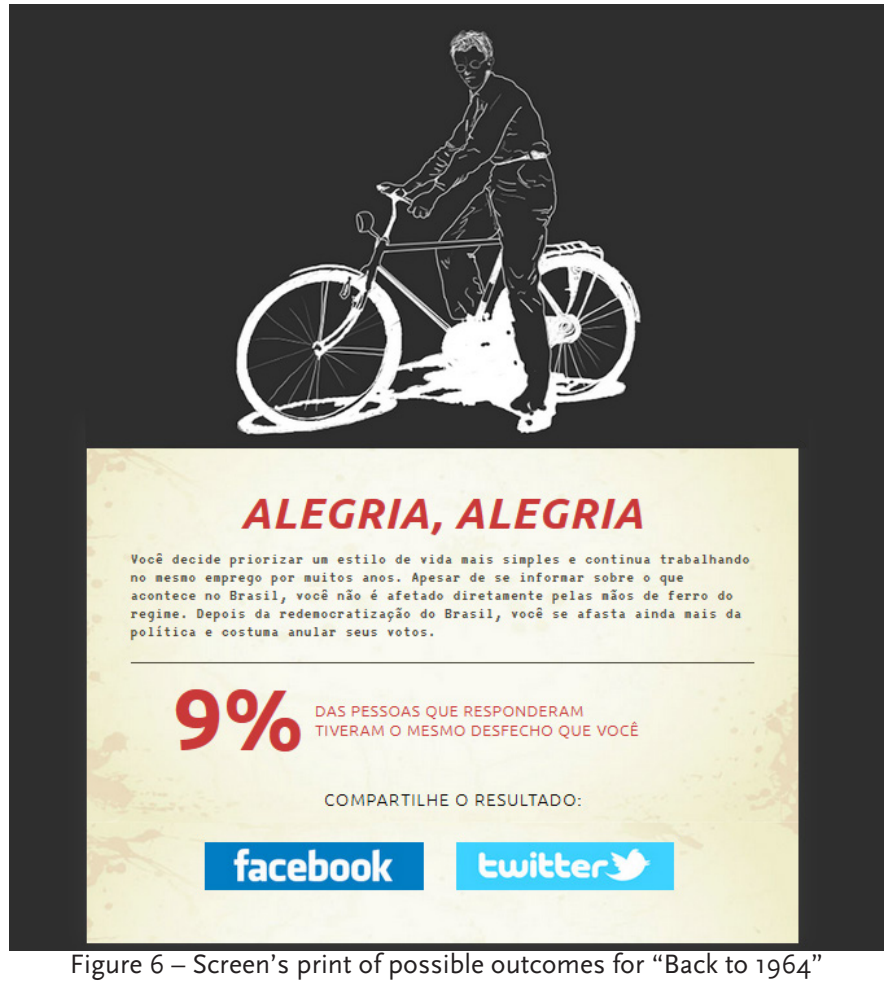

For the player who chose to "change job", the next move is to decide what to do with the bonus received: "Your professional career took off and now you are part of a population that does not have to worry about money, passing unscathed through the 
hardest years of the dictatorship. You receive a year-end bonus. What do you do with the money?" (Redação Super, 2014). Two possibilities arise: "buy a house" or "travel with family". Whatever the choice, the next question is the same: "The military dictatorship has never affected you negatively, now your teen asks your permission to attend one of the demonstrations against the regime. What do you do?" (Redação Super, 2014).

\section{FinAL CONSIDERATIONS}

Papers by Frasca (2001), Bogost (2008), Bogost, Ferrari \& Schweizer (2010), lurgel \& Zagalo (2009), Ferrari (2009), Gonçalves \& Zagalo (2010), Zagalo (2012) and Sicart (2008) formed the basis of this analysis. A number of elements to contextualize the newsgames and relate them to other cultural products were presented, showing the newsgame's potential and limitations, and potential developments of this type of narrative structure in the media environment.

Huizinga (1938: I) suggested "it is in the game and for the game that civilization emerges and develops". Adopting such a perspective provides muscles for thinking about newsgames from the author's perspective, considering the game as a serious matter, which "distinguishes and typifies everything that happens in the world" (Huizinga, 1938: I)

Another important aspect is the study of narrative forms, language and rhetoric, which gives the newsgames a horizon of wider and consistent studies, entering the synchronic and diachronic axis of cultural productions, whose support is the internet.

A third point that enriches the research on the topic, is the fact that many of the scholars are also game developers, i.e. they know the programming logic, what is or what is not possible, the extent to which a newsgame is hampered by code complexity or technological limitations.

The studies mentioned above realize that newsgames have rapidly spread and developed, with concomitant improvements in the playing experience. In an environment of digital convergence (Jenkins, 2010) in which traditional forms of communication face a crisis caused by content consumption produced and distributed by the World Wide Web, newspapers see newsgames as one potentially viable alternative to attract or retain readers.

The experience of the Superinteressante magazine deserves special emphasis, as it is a pioneer of this new journalistic form in Brazil. "Back to 1964: your life under the dictatorship", the newsgame here analyzed, has a low degree of interactivity and is best classified as a reactive game whose structure is based on a few preset options, often intersecting, independent the chosen path. Its expressiveness, derived from the union between a journalistic narrative and the playful character of the game, dispenses more elements to expand the immersion capacity of the game. This gives the game more tension, dynamics and approximation of reality. Perhaps because of these two aspects, the level of engagement has also been small, even the links to share the results via Facebook or Twitter managed to stimulate the debate about the game and its underlying issues.

The guiding theme of the game, the 5oth anniversary of the military coup in Brazil, has become a thorny issue for developers, generating some ethical issues (such as 
"commemorating the 5oth anniversary of the coup") and textual issues (coherence and cohesion are compromised in some moments). Unlike other newsgames developed by Superinteressante, "Back to 1964" seems to have been stuck trying to provide a free viewpoint and to leave the reader/player the mission to tread their own path. Newsgames, as emphasized by the literature, need to find an optimal balance between the playful and the journalistic.

\section{REFERENCES}

Almeida, C. (2003) "Novas Tecnologias e Interatividade: além das interações mediadas", Data Grama Zero, 4 (4):1-12, [online], avaiable at http://www.dgz.org.br/agoo3/Art_01.htm, last visited 05/09/2014.

Blog da Super (2014) De volta a 1964: sua vida em tempos de ditadura, [online], avaiable at http://super.abril. com.br/blogs/superblog/de-volta-a-1964-sua-vida-em-tempos-de-ditadura-por-dentro-do-jogo/, last visited 05/9/2014.

Bogost, I. (2007) Persuasive Games: The Expressive Power of Videogames, Cambridge: The MIT Press.

Bogost, I. (2008) "The Rhetoric of Video Games", The Ecology of Games: Connecting Youth, Games, and Learning. MacArthur Foundation Series on Digital Media and Learning. Cambridge, MA: The MIT Press. 117-140 [online], avaiable at http://nau.edu/CAL/Interdisciplinary-Writing-Program/_Forms/Rhetoric VideoGames_Bogost/, last visited 05/9/2014.

Bogost, I.; Ferrari, S. \& Schweizer B. (2010) Newsgames: Journalism at Play, Cambridge: MIT Press.

ComScore (2014) Dados [online] avaiable at http://publicidade.abril.com.br/marcas/44/internet/ informacoes-gerais, last visited 08/9/2014.

Déda, T. \& Zagalo, N. (2010) "Newsgames e Social Games como ferramentas atuantes em novos modelos comunicativos de engajamento", Videojogos, 129-134 [online], avaiable at https://www.academia. edu/709340/Newsgames_e_Social_Games_como_ferramentas_atuantes_em_novos_modelos_ comunicativos_de_engajamento, last visited 05/9/2014.

Ferrari, S. (2009): Newsgame, or Editorial Game? [online] avaiable at http://simonferrari.com/2009/06/02/ sicartfrasca/, last visited 05/9/2014.

Frasca, G. (2003) Simulation versus Narrative: Introduction to Ludology, New York, Routledge.

Gonçalves, A. \& Zagalo, N. (2010) "Entre a realidade e a virtualidade", Proceedings do SBGames [online] avaiable at https://www.academia.edu/2818922/Entre_a_realidade_ea_virtualidade, last visited 05/9/2014.

Huizinga, J. (1938) Homo Ludens - O Jogo como Elemento da Cultura, São Paulo: Perspectiva. (1971).

Jenkins, H. (2006) Convergence Culture Where Old and New Media Collide, New York: New York University Press.

lurgel, I. A., Zagalo, N. \& Petta, P. (eds) (2009) Interactive Storytelling, Lecture Notes in Computer Science, Heidelberg: Springer Berlin, 234-245.

Machado, A. (1990) A Arte do Vídeo, São Paulo, Brasiliense.

Primo, A. (2003) "Quão interativo é o hipertexto: da interface potencial à escrita coletiva" Fronteiras Estudos Midiáticos, 5 (2): 125-142 [online], avaiable at http://www.ufrgs.br/limc/PDFs/quao_interativo_ hipertexto.pdf, last visited 05/9/2014. 
Redação Super (2014) "De volta a 1964: sua vida em tempos de ditadura. Newsgame" Revista Superinteressante [online], available at http://super.abril.com.br/jogo-ditadura-militar/, last visited 05/9/2014.

Sicart, M. (2008) "Newsgames: theory and design", International Conference on Entertainment Computing Pittsburgh, PA, 27-33 [online], available at http://link.springer.com/chapter/10.1007\%2F978-3-540-892229_4\#page-1, last visited 05/9/2014.

\section{LUDOGRAPHY}

Editora Abril (2014), De volta a 1964: sua vida em tempos de ditadura $®$

Editora Abril (2013), CSI — A ciência contra o crime $®$

Editora Abril (2013), Filosofighters $\circledR$

Editora Abril (2013), O jogo da Máfia $®$

Editora Abril (2013), A evolução do Movimento $®$

Editora Abril (2013), Corrida Eleitoral $®$

Folha de S. Paulo (2013), A Batalha de Belo Monte $®$

Portal de Notícias G1 (2013), Buy buy Brasil $®$

The New York Times (2012), Snow Fall $@$

\section{Bio NOTE}

Lilian Cristina Monteiro França. Doctor Degree in Communication and Semiotics (Pontifical Catholic University of São Paulo). Post-Doctoral studies in Art History (IFCH/ UNICAMP). Professor of Social Communication Department and Masters Programs of Communication and Languages of the Federal University of Sergipe. Develops project with College/ City University of New York, "Subjugated knowledge - permitting narratives to emerge". Published "Caos Espaço Educação" (Annablume), "Da geometria eucliana a geometria fractal - um estudo sobre história da arte» (Educ) e «lmagens e números"(Edufs).

E-mail: liliancmfranca@uol.com.br

Department of Social Communication. Federal University of Sergipe. Campus Universitário "Prof. José Aloísio de Campos". Rodovia Marechal Rondon, s/n. Rosa Elze. 49.100-00o. São Cristóvão - Sergipe - Brazil

* Submitted: 30-11-2014

* Accepted:15-3-2015 